\title{
Financial Capability in Ethiopia: A Case Study of Addis Ababa City
}

\author{
Miheretu Kebede Lemu \\ Lecturer of Finance \& Accounting, Department of PFM and Accounting \\ Ethiopian Civil Service University, Addis Ababa-1000, Addis Ababa, Ethiopia \\ E-mail: 1miheretukebede@gmail.com
}

Received: February 13, 2020 Accepted: March 29, 2020 Published: August 11, 2020

doi:10.5296/ber.v10i3.17508

URL: https://doi.org/10.5296/ber.v10i3.17508

\begin{abstract}
This study investigates financial knowledge, behavior and attitude of individuals to gauge how the financial market evaluates an individual's financial capability and financial decision making. Higher financial knowledge increases the entry into sophisticated financial contracts and the understanding of contemporary featured new financial products as well as good financial decision making. Financial behavior also enhances the financial decision making of those individuals as well as the relationship between individuals and their behavior towards saving, investment, cash and credit. These effects are intensified by individuals' financial behavior, the level of relationship with investments, savings and the use of credit. This study found out that a deeper acquaintance of individuals on financial knowledge, attitude and behaviour results in positive consequences on their relations with financial service providers and in turn promotes to financial capability.
\end{abstract}

Keywords: Financial Capability, Knowledge, behavior, attitude, Addis Ababa, Ethiopia

\section{Introduction}

Previous studies state that financial capability is composed of financial knowledge, financial behaviour and financial attitude (Kempson et al., 2005; Atkinson and Messy, 2012; Collins, 2013; World Bank, 2014a; Grinstein-Weiss et al., 2015; Hui et al., 2016). Given those financial capability measures such as financial knowledge and skills, financial behaviours, awareness, and financial attitudes and requirements are the most essential indicators for measuring financial capability of individuals. One could presume that such financial knowledge could be an essential deriver of financial capability. Without understanding financial issues and knowledge one cannot perform the contemporary sophisticated financial contracts and financial products in a good manner. Financial education, i.e., financial literacy 
and numeracy is very fundamental for understanding and calculating return on investment, credit contracts, interests on savings and inflation. The study identifies the financial behaviour that constitutes the individual financial capability in Addis Ababa Ethiopia. The financial behaviours such as cash, saving, credit, investment behaviours and behaviours that enhance individuals to use wide range of financial services for one's own benefit. The study investigates the financial attitude of individuals that might drive them to use financial products, services and commands their financial behaviours.

Evidence suggests that individuals who lack financial knowledge and financial access are not financially capable (Sherraden, 2013a). Individuals need financial knowledge, skills and financial inclusion in order to become financially capable.

The study was undertaken to find answer for the research questions such as; (1) what is the level of individual's financial Knowledge in Addis Ababa Ethiopia? (2) What does the individual's financial behaviour on investment, saving, credit looks like? (3) How well is an individuals' financial attitude? The overall objective is to examine the individual's financial capability in Addis Ababa, Ethiopia, and it identifies and addresses the issues in the same topic of interest. The study has three specific objectives where the first is to measure the individual's financial knowledge. Besides, the second and the third specific objectives are to examine financial behaviour and attitude respectively and three of them add up together and work for the measurement of financial capability in Ethiopia which is the main objective. The study uses the methodology that can measure the financial capability (financial knowledge, behaviour and attitude) of individuals. Regarding sections of the study, section two deals with review of related literature and section three presents research methodology applied to conduct the study. Section four, on the other hand, deals with the results of analysis and presentation. Section five, finally, presents conclusion and recommendation.

\section{Literature Review}

Financial capability refers to having sufficient financial knowledge (specifically knowledge of financial products, services, institutions and concepts, financial skills and skills of calculating interest payments), financial behaviours (behaviours like cash, saving, credit and investment behaviours) and financial attitude (tendency towards financial practices).

The financial capability is ability to deal with day today financial matters and appropriate management of money (Lusardi, 2011). It is ability of individual to take control and manage finance (Taylor, 2011). It presented by financial knowledge, financial behaviour and financial attitude. Financial knowledge is a product of financial education, learnings and experiences. It is individuals understanding of financial aspects. Financial knowledge is measuring understanding of concept of interest, inflation, saving, investment, credit, and risk diversification (Khan et. al., 2017; Atkinson and Messy 2012; Sherraden, 2013a; World Bank 2014a).

The financial behaviour comprises of cash, saving, credit and investment behaviour of human beings that are relevant to money management. Financial behaviours are behaviours of human related to finance or a collection of an overt financial activities that are affected by 
individuals identity, needs, knowledge, skills, performance, achievement, individual characteristics, significance and Psychological characteristics (Xiao, 2008; Bergner, 2011; Garcia, 2013).

Financial attitude can be achieved through application of appropriate financial practices acquired in knowledge domain. Financial attitude is a tendency toward action or financial practice and deciding on the best after analysis, when making particular investment decision (Eagly and Chaiken, 1993).

Empirical evidences has showed at financial knowledge and its application can enhance for sound financial decision making and boost financial wellbeing of individuals(world Bank, 2014a; Atkinson and Messy 2012). Lack of financial knowledge and unappropriated financial practices of financial knowledge leads vulnerable consumers for financial turmoil due to lack of understanding of financial products and financial contracts (World Bank, 2014a; Atkinson and Messy 2012).

\section{Research Methodology}

The main objective of this study is twofold. The first objective is to measure the score of financial knowledge of individual households in Ethiopia. The Second objective is to measure the financial behaviour of individual households in Ethiopia. The third objective is to measure the financial attitude of individual household in Ethiopia. Over all it measures the financial capability of individuals in Ethiopia (Addis Ababa). Below, we explain the methodology and data that we use in our analysis.

In this study, the researcher employs fifteen measures of financial capability that are categorized into three. These are measures of financial knowledge known as financial knowledge score measures are six: (1) inflation (2) interest rate (3) compound interest (4) Money illusion (5) Risk diversification (6) main purpose of insurance. The arithmetic sum of correct responses of basic financial concepts (1-6) makes up financial knowledge score of individual households. The financial behaviour measures also known as use of saving for emergency funding are six: (1) Savings (2) Borrow from friends or relatives (3) Borrow from working place or employer (4) Borrow from financial institution (5) Borrow from Private informal lender (6)Other(selling assets, working more). The \%age of adults that respond "saving" in response to question: You need Birr 660 for emergency purpose, from which of the following source can you avail the amount needed on spot? All variables related to financial knowledge and behaviour come from survey of individuals, 2020, which was conducted by the researcher. The measures of financial attitude are three (1) saving attitude (2) spending attitude (3) investing attitude.

All data related to financial capability are collected through survey of individuals, which was conducted by the researcher in 2020 using two stage cluster sampling. The primary sampling unit is Addis Ababa City administration ten sub cities. The total of 100 individuals selected randomly, 10 each from ten weredas in Addis Ababa, Ethiopia. The sample includes adults of age above 18 years, all income and educational categories. The needed institutional data collected from the National Bank of Ethiopia. The financial capability problems are identified 
using both the individual survey and institutional secondary data.

\section{Results}

A sample survey of 100 individuals, out of which 59(59\%) male and 41(41\%) female are taken to study the financial capability of individuals in Addis Ababa, Ethiopia. The survey of the adult's financial knowledge shows that, in Ethiopia, 52\% of individuals have basic understanding of concept of simple interest (see table 1 below). This indicates that approximately half of adults lack basic knowledge of simple interest.

Table 1. Understanding of Concept of Simple Interest

\begin{tabular}{|l|l|l|}
\hline $\begin{array}{l}\text { If you put Br.500 into a saving deposit at a bank with a fixed interest } \\
\text { rate of } 7 \% \text { per annum. If it is the lump sum amount made at the end } \\
\text { and you have not withdrawn the money. What will be the amount of } \\
\text { your deposit at the end of the year 1? }\end{array}$ & Frequency & Percent \\
\hline Br. 505 & 10 & 10.0 \\
\hline Br. 525 & 20 & 20.0 \\
\hline Br. 535 & 52 & 52.0 \\
\hline The answer is not given. & 18 & 18.0 \\
\hline Total & 100 & 100.0 \\
\hline
\end{tabular}

Source: Analysis of Survey result, 2020

In Ethiopia, 53\% of adults have basic understanding about concept of compound interest (see table 2). In contrast, the result shows that $47 \%$ of individuals do not know the concept of compound interest (time value of money concept). Thus, this result implies that the individuals can face a lot of barriers when they go for loan contracts and investments.

Table 2. Understanding of Concept of Compound Interest

\begin{tabular}{|l|l|l|}
\hline $\begin{array}{l}\text { If you put Br.500 into a saving deposit at a bank with a fixed interest } \\
\text { rate of } 7 \% \text { per annum. If it is the lump sum amount made at the end } \\
\text { and you have not withdrawn the money. What will be the amount of } \\
\text { your deposit at the end of the year 6? }\end{array}$ & Frequency & Percent \\
\hline greater than Br.750 & 13 & 13.0 \\
\hline Br.750 & 53 & 53.0 \\
\hline Less than Br.750 & 21 & 21.0 \\
\hline the answer is not given (compound interest) & 13 & 13.0 \\
\hline Total & 100 & 100.0 \\
\hline
\end{tabular}

Source: Analysis of Survey result, 2020

In Ethiopia, 21\% of adults understand about the effect of inflation on the savings (see table 3). On the other hand, $79 \%$ of individuals do not know about the effect of inflation in saving. 


\section{Mll Macrothink}

Business and Economic Research

ISSN 2162-4860

2020, Vol. 10, No. 3

This indicates lack of financial knowledge which is useful for financial decision making like saving, lending and investing.

Table 3. Understanding of effect of inflation on saving

\begin{tabular}{|l|l|l|}
\hline $\begin{array}{l}\text { If the price of the goods and services increases } \\
\text { steadily and with speed, it indicates high inflation }\end{array}$ & Frequency & Percent \\
\hline False & 79 & 79.0 \\
\hline True & 21 & 21.0 \\
\hline Total & 100 & 100.0 \\
\hline
\end{tabular}

Source: Analysis of Survey result, 2020

In Ethiopia, 30.2\% of adults understand method of risk diversification and $69.8 \%$ of individuals didn't understand the method of risk diversification. (See table 4). This indicates that only few people have the knowledge of risk diversification which is a very important financial knowledge for making any kind of investment.

Table 4. Understanding of Method of risk diversification

\begin{tabular}{|l|l|l|}
\hline $\begin{array}{l}\text { Reducing risk is possible by investing in a single investment like } \\
\text { shares, rather than diversifying in form of saving in bank, buying } \\
\text { bonds, and investing in real properties. }\end{array}$ & Frequency & Percent \\
\hline False & 29 & 30.2 \\
\hline True & 67 & 69.8 \\
\hline Total & 96 & 100.0 \\
\hline
\end{tabular}

Source: Analysis of Survey result, 2020

In Ethiopia, 19.2\% of adults understand the main purpose of insurance (see table 5). This shows that more than $80 \%$ of adults have no knowledge regarding the purpose of insurance. In jurisdiction, there is a little awareness about the insurance products and their benefits. In addition to lack of money as a fundamental problem for purchase of insurance, People believe that purchase of insurance is like calling an accident and bad luck. This is due to low level of financial knowledge. This indicates that individual intention towards making sophisticated financial contract is low and poor financial decision making can be made.

Table 5. Understanding of Main Purpose of insurance

\begin{tabular}{|l|l|l|}
\hline $\begin{array}{l}\text { The main aim of insurance policy is to keep } \\
\text { you protected from death. }\end{array}$ & Frequency & Percent \\
\hline False & 19 & 19.2 \\
\hline True & 80 & 80.8 \\
\hline Total & 99 & 100.0 \\
\hline
\end{tabular}


Source: Analysis of Survey result, 2020

The individuals having low financial knowledge are more exposed for adverse selection and moral hazard problems, in circumstances in which the economy is operating under recession and depression. Financial knowledge is fundamental to understand complex contracts in order to resolve such problem.

In Ethiopia, 59.2\% of adults understand about the concept of money illusion (see table 6). This shows that the individuals understanding of money purchasing power be affected by $14 \%$ prevailing inflation of the nation is good. In other word, $40 \%$ of individuals didn't understand about the concept of money illusion.

Table 6. Understanding of decisiveness of money or cash

\begin{tabular}{|l|l|l|}
\hline $\begin{array}{l}\text { It is assumed that you have Birr 1000,000 today. If you do not } \\
\text { invest into or save in bank account you will have the same amount } \\
\text { in next year, under consideration of Ethiopian economy. }\end{array}$ & Frequency & Percent \\
\hline False & 58 & 59.2 \\
\hline True & 40 & 40.8 \\
\hline Total & 98 & 100.0 \\
\hline
\end{tabular}

Source: Analysis of Survey result, 2020

Individuals are asked, you need Birr 660 for emergency purpose, from which of the following source can you get the amount needed on spot. The analysis of individual financial behavior indicates the following results.

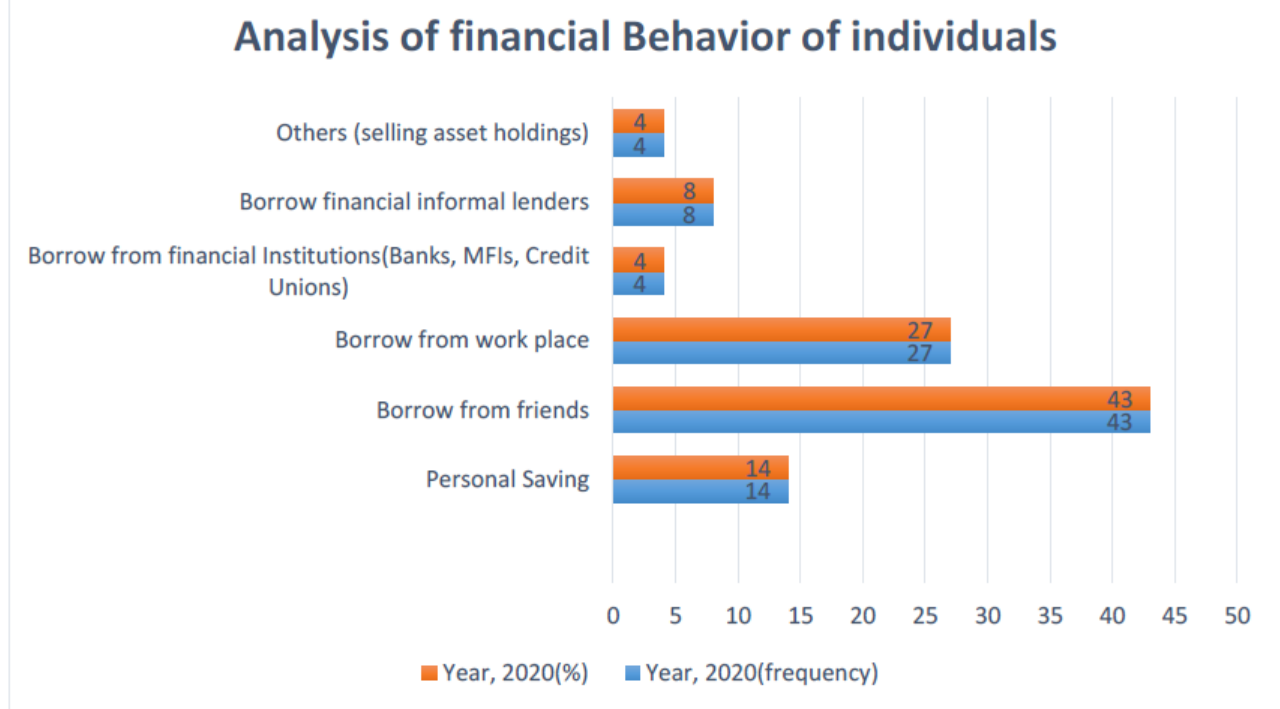

Figure 1. Analysis of financial Behavior of individuals

Source: Analysis of Survey result, 2020 


\section{Mll Macrothink}

Business and Economic Research

ISSN 2162-4860

2020, Vol. 10, No. 3

The finding shows that only $14 \%$ of individuals can get emergency fund from their personal savings. This indicates that individual's dependence on their personal saving at time of emergency is very low in Ethiopia. On the other hand, 43\% reported that they borrow from friends (Figure 1). And, this indicates that borrowing from friends at the time of emergency is the most predominant source of funds for individuals in Ethiopia. The 27\% and 8\% respondents reported that they borrow from workplace and informal money lenders respectively. Therefore, this implies that in Ethiopia, there is still large room for informal money lenders, regardless of the government's control. On the other hand, only $4 \%$ of individuals reported that they borrow from financial institutions and this shows the existence of huge credit exclusion in Ethiopia. Finally 4\% reported that the other sources such as selling of their asset holdings for purpose of emergency fund. And this shows that individuals lose their precious assets at the time of emergency, even if they need fewer amounts of cash than the value of the asset placed for sales.

In Ethiopia, 65\% of adults do not save money (see table 7). When individuals earn money they immediately spend it for consumption purpose which implies low attitude towards saving and high attitude for consumption.

Table 7. Analysis of financial attitude of individuals

\begin{tabular}{|l|l|l|}
\hline $\begin{array}{l}\text { You got Birr 10,000 today and you may spend it for consumption, if that } \\
\text { is true, You don't care about tomorrow, tomorrow care about itself. }\end{array}$ & Frequency & $\%$ \\
\hline No & 35 & 35.0 \\
\hline Yes & 65 & 65.0 \\
\hline Total & 100 & 100.0 \\
\hline
\end{tabular}

Source: Analysis of Survey result, 2020

In Ethiopia, $63 \%$ of adults spend money immediately (see table 8). Individuals believe that money is given for consumption or spending rather than saving. Perhaps this behavior appears to be emanated from low income living and lack of self-control. This indicates the attitude towards consumption is high and saving is low

Table 8. Analysis of financial attitude of individuals

\begin{tabular}{|l|r|r|}
\hline $\begin{array}{l}\text { You got Birr 10,000 today and you may spend it for consumption, if } \\
\text { that is true, Money is given for you to spend it, rather than save it. }\end{array}$ & Frequency & $\%$ \\
\hline No & 37 & 37.0 \\
\hline Yes & 63 & 63.0 \\
\hline Total & 100 & 100.0 \\
\hline
\end{tabular}

Source: Analysis of Survey result, 2020

In Ethiopia, 56\% of adults do not save for investment (see table 9). This shows that more than 
half of adults did not understand that saving is very crucial for future investment. Rather the attitude of individuals is to spend money for consumption purpose. This indicates that the attitude towards long-term investment is low and spending is high.

Table 9. Analysis of financial attitude of individuals

\begin{tabular}{|l|l|l|}
\hline $\begin{array}{l}\text { You got Birr 10,000 today and you may spend it for consumption, if } \\
\text { that is true, You satisfy in spending money today than saving it for } \\
\text { long-term. }\end{array}$ & Frequency & $\%$ \\
\hline No & 44 & 44.0 \\
\hline Yes & 56 & 56.0 \\
\hline Total & 100 & 100.0 \\
\hline
\end{tabular}

Source: Analysis of Survey result, 2020

\section{Conclusion and Recommendations}

\subsection{Conclusion}

The study focused on three specific objectives where the first objective is to measure the individual's financial knowledge in Addis Ababa, Ethiopia. The second objective, on the other hand, is to evaluate the individual's financial behaviour in the study area. At last, the third objective is to investigate the individual's financial attitude in Ethiopia. The investigation of the financial knowledge of individuals find that $52 \%$ and $53 \%$ of individuals can understand the concept of simple and compound interest respectively, whereas $21 \%$ know about the inflation's impact on the savings, and $30.2 \%$ of individuals understand risk diversification concept. Individuals' financial knowledge is very critical for financial decision making and financial matters. However, the findings show that financial knowledge is very low in Addis Ababa, Ethiopia. Regarding the financial behaviour of individuals, only $12 \%$ of adults can cover emergency need of cash from their personal savings, whereas $43 \%$ of adults get emergency loan from friends and relatives, and $29 \%$ of individual's loan from work place. These show that the financial behavior of individuals such as saving, credit and investment behaviors are weak in Addis Ababa, Ethiopia. This indicates that they are vulnerable at the event of shocks and not resilient at time of shock.

The financial attitude of individuals shows that $65 \%$ of individuals tend to not to save money and $63 \%$ of adults enjoy spending money and $56 \%$ tend to not save money for long-term or short-term investment. These show that the individual's financial attitude is very weak in in the study area and the tendency of individuals towards action or financial practice is also very low. Thus, this attitude may force majority of individuals to live at or below poverty line.

\subsection{Recommendation}

The financial education for pupils through well-designed curriculum is believed to enhance the financial knowledge. The regular non-formal education about financial concepts via national media in form of advertising and entertainment can be used as a good intervention 
measures for old aged people. Providing of trainings and teachable activities via social media and making financial literacy program as one of plan and taking initiative by the National Bank of Ethiopia can tend to minimize problems and enhance individual's wellbeing.

\section{References}

Atkinson, A., \& Messy, F. A. (2012). Measuring Financial Literacy: Results of the OECD INFE Pilot Study. OECD Working Papers on Finance, Insurance and Private Pensions, No. 15, OECD. [Online] Available:

https://www.oecd-ilibrary.org/docserver/5k9csfs90fr4-en.pdf?expires=1592268563\&id=id\&a ccname $=$ guest $\&$ checksum $=$ CA6A35B72AE0CAB7304E5683E86109B0

Bergner, R. M. (2011). What is behavior? And so what? New Ideas in Psychology, 29(2), 147-155. https://doi.org/10.1016/j.newideapsych.2010.08.001

Collins, J. M. (2013). The impacts of mandatory financial education: Evidence from a randomized field study. Journal of Economic Behavior \& Organization, 95, 146-158. https://doi.org/10.1016/j.jebo.2012.08.011

Eagly, A. H., \& Chaiken, S. (1993). The psychology of attitudes. New York: Harcourt, Brace, \& Janovich. Psychology and Marketing, 12. 459-466. [Online] Available:

https://www.researchgate.net/publication/258879638_A_review_Eagly_A_H_Chaiken_S_19 93_The_psychology_of_attitudes_New_York_Harcourt_Brace_Janovich/link/5bc7b304299bf 17a1c573701/download

Garcia, M. J. R. (2013). Financial education and behavioural finance: New insights into the role of information in financial decisions. Journal of Economic Surveys, 27(2), 297-315. [Online] Available:

https://onlinelibrary.wiley.com/doi/pdf/10.1111/j.1467-6419.2011.00705.x?casa_token=hW_ DQ2NOQ8AAAAA:eFLyAjnTFj4N88BXT6hlka1ROGw2QNFAlq_qPAon2j12M4EYvB8xT L2acBcTHUmiqXvx4ZCR3FlS8vDB

Grinstein-Weiss, M., Guo, S., Reinertson, V., \& Russell, B. (2015). Financial education and savings outcomes for low-income IDA participants: Does age make a difference? Journal of Consumer Affairs, 49(1), 156-185. https://doi.org/10.1111/joca.12061

Hui, T. S., Nguyen, C., Palameta, B., \& Gyarmati, D. (2016). The role of financial literacy in financial decisions and retirement preparedness among seniors and near-seniors (pp. 1-79). Canada: Financial Consumer Agency of Canada. [Online] Available: http://www.srdc.org/media/199921/fcac-full-report-on-retirement-preparedness-en.pdf

Kempson, E., Collard, S., \& Moore, N. (2005). Measuring financial capability: An exploratory study. London: Financial Services Authority. [Online] Available:

http://www.bristol.ac.uk/media-library/sites/geography/migrated/documents/pfrc0510.pdf

Khan, M. N., Rothwell, D. W., Cherney, K., \& Sussman T. (2017). Understanding the Financial Knowledge Gap: A New Dimension of Inequality in Later Life. Journal of Gerontological Social Work, 60(6-7), 487-503. [Online] Available: 


\section{Macrothink}

Business and Economic Research ISSN 2162-4860 2020, Vol. 10, No. 3

https://www.researchgate.net/publication/316047150_Understanding_the_Financial_Knowle dge_Gap_A_New_Dimension_of_Inequality_in_Later_Life/link/5d09b4e7458515ea1a70afb 1/download

Lusardi, A. (2011). American's Financial Capability. Working Paper 17103, National Bureau of Economic Research. https://doi.org/10.3386/w17103

Sherraden, M. S. (2013a). Building blocks of financial capability. In J. Birkenmaier, M. S. Sherraden \& J. Curley (Eds.), Financial education and capability: Research, education, policy, and practice (pp. 3-43). New York, NY: Oxford University Press. [Online] Available: https://www.oxfordscholarship.com/view/10.1093/acprof:oso/9780199755950.001.0001/acpr of-9780199755950-chapter-1

Taylor, M. (2011). Measuring financial capability and its determinants using survey data. Social Indicators Research, 102(2), 297-314. https://doi.org/10.1007/s11205-010-9681-9

World Bank. (2014a). Global Financial Development Report 2014: Financial Inclusion. Washington, DC: World Bank. https://doi.org/10.1596/9780821399859

Xiao, J. J. (2008). Applying Behavior Theories to Financial Behavior. [Online] Available: https://www.researchgate.net/publication/226315836_Applying_Behavior_Theories_to_Fina ncial_Behavior/link/55c20b3e08aeca747d5dc0e1/download

\section{Copyright Disclaimer}

Copyright for this article is retained by the author(s), with first publication rights granted to the journal.

This is an open-access article distributed under the terms and conditions of the Creative Commons Attribution license (http://creativecommons.org/licenses/by/4.0/). 